Review Article

\title{
PHYTOPHARMACOLOGICAL REVIEW OF KNEMA ATTENUATA (HOOK F. AND THOMSON) WARB
}

\author{
SUPRIYA RAJA H. ${ }^{*}{ }^{*}$, SREEKANTH G. B. ${ }^{2}$ \\ ${ }^{1 *}$ Department of Pharmacology, College of Pharmaceutical Sciences, Govt. Medical College, Trivandrum, ${ }^{2}$ ICAR-Central Coastal Agricultural \\ Research Institute, Old Goa 403402, Goa, India \\ "Email: sraja968@gmail.com
}

Received: 25 Jan 2021, Revised and Accepted: 20 Mar 2021

\begin{abstract}
Knema attenuata, a member of Myristicaceae family and commonly known to world as 'wild nutmeg' is broadly used in folk medicine for treating ailments such as jaundice, chronic fever, inflammations, spleen disorders, breathing disorders and impaired taste sensation. This review article aims to compile all the updated information on the phytochemical and pharmacological activities of plant Knema attenuata. Studies indicate that different parts such as aril, seed and stem bark of the plant is rich in phenolics, flavonoids, tannins, steroids, terpenes, resins and glycolipids. Moreover, stem bark of Knema attenuata contains a lignan 'attenuol' with diverse pharmacological activities. In addition, different extracts of plant parts have been found to possess various pharmacological activities such as antioxidant, antifungal, larvicidal, analgesic, anti-inflammatory, antihyperlipidemic, and hepatoprotective activities. More research on phytochemical composition and therapeutic implications are recommended.
\end{abstract}

Keywords: Folk medicine, Knema attenuata, Lignan, Stem bark

(C) 2021 The Authors. Published by Innovare Academic Sciences Pvt Ltd. This is an open access article under the CC BY license (https://creativecommons.org/licenses/by/4.0/) DOI: https://dx.doi.org/10.22159/ijcpr.2021v13i3.42089 Journal homepage: https://innovareacademics.in/journals/index.php/ijcpr

\section{INTRODUCTION}

Plants have always played a remarkable role in human health care since ancient times. Plant parts, potions, and powders have been used, for centuries, by traditional herbal healers for curing ailments. It is likely that the deep knowledge on herbal medicines and the methods of application for treating disorders have been passed on from generation to generation either verbally or in writing [1]. To date, a large number of plant extracts have been screened to isolate and purify the bioactive components which can be potential drug leads. Accordingly, the priority of the pharmaceutical industry shifted to natural product-based drug discovery, which could be of desired efficacy and with higher safety margin [2]. Knema is a genus belonging to Myristicaceae family, distributed in tropics and subtropics of Indomalesia region which includes around 93 species widely used in folk medicine [3]. This genus mostly consists of smallmedium trees has been used to treat sores, pimples, rheumatism, and cancer. The presence of a variety of natural compounds such as acetophenone, substituted stilbene, lignan, flavonoid, alkyl/acyl resorcinol, and phenylalkylphenol derivatives have been reported in the barks and seeds of genus Knema which exhibits antibacterial, antinematodal, anti-inflammatory, cytotoxicity, and acetylcholinesterase inhibitory activities [4]. A total of 8 species and 2 sub species were found in India out of which Knema attenuata (Hook. f. and Thomson) Warb. and Knema andamanica (Warb.) W. J. de Wilde were indigenous to India [5]. Knema attenuata or Myristica attenuata, commonly known as 'wild nutmeg' is an endemic tree species in Western Ghats which has a characteristic red resin in their bark. Therefore, this species has the word 'blood' in their vernacular names in different regions [6]. It is called chennelli, chorapatri, chorappai, chorapali etc. in Malayalam, chora pathiri in Tamil, Rakta mara in Kannada and ran jayphal in Marathi and Konkani [7]. This comes under IUCN (International Union for Conservation of Nature and Natural Resources) red list category of threatened species [8]. This medicinal plant is used traditionally for the treatment of ailments, such as jaundice, chronic fever, inflammations, spleen disorders, breathing disorders, and impaired taste sensation. Generally, K. attenuata is utilized either as whole plant or its specific parts (stem bark, fruit) for medicinal purpose [9]. However, this species is not sufficiently exploited in a phytochemical and pharmacological point of view. Therefore, this review aims to highlight the ethnopharmacological importance of this species with an existing opportunity to explore new bioactive molecules of pharmacological importance.

\section{Taxonomical classification}

Kingdom: Plantae

Division: Tracheophyta

Class: Magnoliopsida

Order: Magnoliales

Family: Myristicaceae

Genus: Knema

Species: attenuata

\section{Botanical description}

Knema attenuata is a medium sized tree that grows about $7-30 \mathrm{~m}$ in height. It is commonly found in semi-evergreen to evergreen forests of Western Ghats-South, Central and south Maharashtra Sahyadris. Branches are arranged in whorls, horizontal; whereas young branchlets are with round, rusty tomentose. Bark is usually smooth, brownish and blaze red with irregular exfoliation which exudes red sap from cut end. Leaves are simple, alternate, rusty velvety when young and hairless when mature, narrow oblong to oblong or narrow-elliptic to lance shaped, apex acuminate, acute to rounded at the base, margin entire, leathery, shining above and glaucous beneath. Midrib is raised above; lateral nerves are prominent, 13-21 pairs, joining along the margin. Flowers are unisexual, dioecious and distinctly stalked. Male flowers arise in short axillary peduncle, rusty velvety. Female flowers arise 1-3, in leaf arils. Fruit is oblong-ovoid and seeds solitary with crimson red fleshy aril. Flowering season is from November to February and the fruits are formed in February to May $[5,10,11]$

\section{Phytochemical constituents}

The $K$. attenuata plant contains various phytochemicals such as flavonoids, glycosides, alkaloids, steroids, triterpenoids, lignans, phenolic compounds, tannins and carbohydrates. Preliminary phytochemical screening of ethanolic and hexane extracts of seeds as well as ethanolic and chloroform extracts of aril of the plant 
revealed the presence of phenolics, flavonoids, tannins, steroids, terpenes, resins and glycolipids. The highest concentration of phenolic compounds and flavonoids were observed in chloroform extract of aril. Quercetin was the major phenolic compound 0.51 $\mathrm{mg} / 100 \mathrm{mg}$ ) which was obtained in the ethanolic extract of seed [12]. The phytochemical screening of stem bark extract of $K$. attenuata also confirmed the presence of phenolics in the extract. Further, the total amount of phenolic compounds and flavonoids present in the extract were found to be equivalent to $387.6 \mu \mathrm{g} \mathrm{ml}^{-1}$ of gallic acid and $84.12 \mathrm{\mu g} \mathrm{ml}^{-1}$ of quercetin respectively [13]. Analysis of component fatty acids and compositions of oils and fats of Knema attenuata using gas-liquid chromatography showed the presence of myristic and palmitic acid along with fats containing $40 \%$ resinous matter [14]. A lignan "attenuol" was isolated from the stem bark of Knema attenuata which was closely related to the other lignans identified from plants of Myristicaceae family [15]. However, there are only a few reports available regarding the phytochemical content of this plant; therefore, a lot more can still be explored.

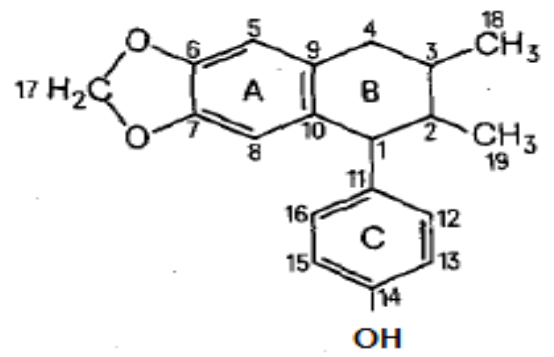

Fig. 1: Chemical structure of lignan attenuol isolated from stem bark of $K$. attenuata

\section{Pharmacological reports}

The available literature reveals the ethnopharmacological importance of this species with the help of various pharmacological investigations carried out on plant parts. A brief summary of the findings of these studies has been presented below.

\section{Antioxidant activity}

Antioxidants are free radical scavengers in the body. Excessive free radical generation due to exposure to external sources such as toxins leads to an antioxidant-free radical imbalance. The oxidative stress caused by this imbalance trigger various diseases such as coronary heart disease, atherosclerosis and cancer [16]. Phytoconstituents such as phenolics and flavonoids having antioxidant potential can be isolated as well as used as a remedy against oxidative stress and related diseases [17].

The K. attenuata chloroform extract of aril showed DPPH and H2O2 scavenging activities of $15.0 \mu$ moles/15 min/100 mg and $12.4 \mu$ moles/10 min/100 mg extracts respectively. Besides, the chloroform extract also exhibited a maximum concentration of phenolics $(96.1 \mathrm{mg} / \mathrm{g}$ ) and flavonoids $(64.2 \mathrm{mg} / \mathrm{g})$ [12]. A study conducted on ethanolic stem bark extract of $K$. attenuata also showed promising antioxidant activity. A maximum percentage inhibition of DPPH free radical (87\%) was obtained at a concentration of $100 \mu \mathrm{g} \mathrm{ml}^{-1}$ with an IC50 value of $17.97 \mu \mathrm{g} \mathrm{ml}^{-1}$. Further, quantitative analysis of phytochemicals revealed that the total amount of phenolic compounds and flavonoids present in the extract was equivalent to $387.6 \mathrm{\mu g} \mathrm{ml}^{-1}$ of gallic acid and $84.12 \mu \mathrm{g} \mathrm{ml}-$ ${ }^{1}$ of quercetin respectively [13]

\section{Antimicrobial activity}

Antimicrobial agents which reduce morbidity and mortality due to microbial infections are on high demand especially in the current scenario. Emergence of mutant or resistant pathogenic microbes have further enhanced the need for newer agents. Therefore, it is preferable to screen phytoconstituents with remarkable antimicrobial activity. A moderate antifungal activity against $C$. albicans and a high antimicrobial activity against $S$. aureus $(12563 \pm 55.08$ and $12541 \pm 55.1$ respectively) was exhibited by chloroform extract of aril and hexane extract of seed of $K$. attenuata [12]. The antimicrobial activity was also studied in ethanolic stem bark extract of $K$. attenuata and was found to have a mild antibacterial but moderate antifungal activity [18].

\section{Larvicidal activity}

Phytochemicals which possess larvicidal activity are environment friendly and therefore, an excellent alternative for synthetic pesticides [19]. The larvicidal activity of aril and kernel extracts of $K$. attenuata was investigated on larvae of Aedes albopictus Skuse and Anopheles stephensi Liston. Chloroform extracts of aril and ethanol extracts of kernel exhibited higher toxicity against both larval forms. Chloroform extracts of aril showed $100 \%$ mortality at the concentration of $500 \mathrm{ppm}$ with lowest LC50 value (141 ppm and 160 ppm against Aedes albopictus and Anopheles stephensi respectively [20].

\section{Analgesic activity}

The antinociceptive potential of the crude extract of aril and seed of $K$ attenuata were studied using in vivo models such as hot plate method and tail immersion test. Both the extracts reported significant dose dependent analgesic activity up to $400 \mathrm{mg} / \mathrm{kg}$. Higher latency to hot plate and tail withdrawal reflex was exhibited by the ethanolic extract of aril, demonstrating its analgesic property [21].

\section{Anti-inflammatory activity}

As a folk medicine, $K$. attenuata is well known for its antiinflammatory properties as well. In an experimental study based on rat model, the ethanolic stem bark extract of $K$. attenuata was administrated orally, to evaluate the anti-inflammatory response. The screening of anti-inflammatory activity was carried out using carrageenan induced paw edema model and cotton pellet induced granuloma model (for acute and subacute phase respectively). Ethanolic extract $(500 \mathrm{mg} / \mathrm{kg})$ showed a significant percentage inhibition of $60.83 \%$ against the increase in paw volume as well as inhibited the granuloma formation, indicating the possible mechanism as inhibition of mediators behind its anti-inflammatory activity. Moreover, the anti-inflammatory activity of extract was further confirmed in vitro using RAW 264.7 macrophage cell lines [22].

Furthermore, the anti-inflammatory activity of seed and aril extracts were examined on rats using carrageenan induced paw edema model. Anti edemal capacity was demonstrated after $3 \mathrm{~h}$ of edema induction The paw volume $(\mathrm{ml})$ was found to be decreased in groups treated with ethanolic extract of aril and seed $(0.73 \pm 0.02$ and $0.78 \pm 0.02$ respectively) compared to that in control $(1.36 \pm 0.05)$ [21].

\section{Antihyperlipidemic activity}

Hyperlipidemia is one of the major risk factors for premature development of diseases such as atherosclerosis, hypertension and coronary artery disease. Enhanced endogenous synthesis or absorption leads to elevated lipid levels which can be reduced by the use of antihyperlipidemic agents. Therefore, screening of antihyperlipidemic agents are carried out in laboratory animals in which evaluation of both the factors are possible [23].

The antihyperlipidemic activity of seed and aril extracts of $K$. attenuata were carried out using Triton X-100 induced hyperlipidemic assay. Both the extracts showed significant dose dependent antihyperlipidemic activity. At a dose of $400 \mathrm{mg} / \mathrm{kg}$ the serum total cholesterol, triglycerides, low density lipoprotein (LDL), and very low-density lipoprotein (VLDL) were found to be reduced compared to the hyperlipidemic control groups [21].

\section{Hepatoprotective activity}

The Phyto therapeutic approach to modern drug development has always encouraged the recognition and utilization of traditional medicinal plants with remarkable hepatoprotective and curative properties [24]. A study was conducted to demonstrate the hepatoprotective activity of ethanolic stem bark extract of Knema attenuata both in vivo and in vitro which proves its claims to be a 
folk medicine. The hepatoprotective activity was assessed in rat model treated with the hepatotoxic compound, $\mathrm{CCl}_{4}$ which caused severe liver injury. Pretreatment with ethanolic stem bark extract before $\mathrm{CCl}_{4}$ introduction could significantly restrain the elevated level of liver enzymes in serum, biomarkers that indicate hepatotoxicity. Furthermore, the extract could reverse the depletion of glutathione by $\mathrm{CCl}_{4}$ and also could reduce the elevated MDA level back to their normal levels in serum as well. In vitro study was conducted on HepG2 cell lines, in which a dose dependent increase in percentage viability (44.33\%-57.41\%) was shown by ESBE treated cells, exposed to $\mathrm{CCl}_{4}$. The mechanism of hepatoprotection can be attributed to its antioxidant potential. Therefore, $K$. attenuato can be useful as an alternative in several diseases that cause oxidative stress [25].

\section{CONCLUSION}

This review article demonstrates the traditional importance of the plant Knema attenuata. Preliminary analysis revealed the presence of active phytoconstituents which are responsible for its reported pharmacological activities. Although the results from this review are quite promising to prove the folk use of Knema attenuata, quite a lot of limitations exist in current literature. Further studies on phytoconstituents are required to know the proper mechanism of action behind its therapeutic application. It's also necessary to focus on other pharmacological activities or therapeutic possibilities of Knema attenuata.

\section{ACKNOWLEDGEMENT}

The authors extend a deep sense of gratitude to Mr. Suku, associate professor (Pharmacology), College of Pharmaceutical sciences, Trivandrum for his guidance and support.

\section{FUNDING}

Nil

\section{AUTHORS CONTRIBUTIONS}

Conception and design, acquisition, analysis and interpretation of data and writing of manuscript were done by the corresponding author. Reviewing and editing were carried out by the second author.

\section{CONFLICTS OF INTERESTS}

The authors declare no conflicts of interest in preparing this article.

\section{REFERENCES}

1. Balunas MJ, Kinghorn AD. Drug discovery from medicinal plants. Life Sci 2005;78:431-41.

2. Moses T, Goossens A. Plants for human health: greening biotechnology and synthetic biology. J Exp Bot 2017;68:400911.

3. Mabberley JD. Mabberley's plant book: a portable dictionary of plants, their classification and uses. $4^{\text {th }}$ edition. Cambridge University Press: London; 2018. p. 1102.

4. Salleh WMNHW, Ahmed F. Phytochemistry and biological activities of the genus Knema (Myristicaceae). Pharm Sci 2017;23:249-55.

5. Banik D, Bora PP. A taxonomic study on the diversity of Indian Knema Lour. (Myristicaceae). Taiwania 2016;6:141-58.
6. https://indiabiodiversity.org/species/show/13965 [Last accessed on 10 Dec 2020]

7. https://www.flowersofindia.net/catalog/slides/Wild\%20Nut meg.html. [Last accessed on 10 Dec 2020]

8. Hedge K, Hedge R, Ahir KC, Gunaga S. Population structure of Knema attenuata (J. Hk. and Th)-a red listed medicinal tree species in Northern Western ghats of Karnataka, India. Med Plants-Int J Phytomed Rel Indus 2015;7:41-7.

9. Khare CP. Indian medicinal plants: an illustrated dictionary. New Delhi: Springer; 2007.

10. Sankara Rao K, Swamy RK, Kumar D, Arun Singh R, K Gopalakrishna Bhat. Flora of Peninsular India; 2019. http://peninsula.ces.iisc.ac.in/plants.php?name=Knema attenuata. [Last accessed on 10 Dec 2020]

11. Ravikumar K, Ved DK. One hundred red listed medicinal plants of conservation concern in Southern India. Bangalore: foundation for revitalization of local health traditions; 2000. p. 219-22.

12. Vinayachandra, Chandrashekhar KR. Phenolic contents of Knema attenuata fruits and their bio active potential. J Herbs Spices Med Plants 2014;20:183-95.

13. Raja HS, J Suku. Phytochemical screening and in vitro antioxidant activity of Knema attenuata (Hook. Fand Thomson) warb stem bark extract. IJPSR 2019;10:4238-44.

14. Sreenivasan B. Component fatty acids and composition of some oils and fats. J Am Oil Chem Soc 1968;45:259-65.

15. Joshi BS, Ravindranath KR, Viswanathan N. Structure and stereochemistry of attenuol, a new lignan from Knema attenuata (Wall) warb. Cell Mol Life Sci 1978;20:422-3.

16. Pizzino G. Oxidative stress: harms and benefits for human health. Oxid Med Cell Longev; 2017.

17. Tungmunnithum D, Thongboonyou A, Pholboon A, Yangsabai A. Flavonoids and other phenolic compounds from medicinal plants for pharmaceutical and medical aspects: an overview. Medicines (Basel) 2018;5:93.

18. Raja S, J Suku. In vitro evaluation of antimicrobial activity of Knema attenuata stem bark extract. IAJPR 2017;7:242-7.

19. Ghosh A, Chowdhary N, Chandra G. Plant extracts as potential mosquito larvicides. Indian J Med Res 2012;135:581-98.

20. Vinayachandra R, Shwetha, Chandrashekhar KR. Larvicidal activities of Knema attenuata (Hook. F. and Thomson) warb. (Myristicaceae) extracts against aedes albopictus skuse and anopheles stephensi liston. Parasitol Res 2011;109:1671-6.

21. Vinayachandra KR, Chandrashekhar P, Shama, Shastry S. Analgesic, anti-inflammatory and antihyperlipidemic activities of Knema attenuata, an endemic plant of southern India. Phytotherapie 2019;17:188-95.

22. Raja S. Anti-inflammatory activity of Knema attenuata (Hook. F and Thomson) Warb ethanolic stem bark extract in albino wistar rats. AJPCR 2019;12:330-4.

23. Sikarwar MS, Patil MB. Antihyperlipidemic activity of Salacia chinensis root extracts in triton induced and atherogenic dietinduced hyperlipidemic rats. Indian J Pharmacol 2012;44:88-92.

24. Kumar HC, Ramesh A, Kumar JNS, Ishaq BM. A review on hepatoprotective activity of medicinal plants. IJPSR 2011;2:501-15.

25. Raja S. Hepatoprotective activity of ethanolic stem bark extract of Knema attenuata (Hook. Fand Thomson) warb. IJPPS 2020;12:78-82. 